NBER WORKING PAPER SERIES

PERFORMANCE PAY AND PRODUCTIVITY

Edward P. Lazear

NBER Working Paper 5672

\author{
NATIONAL BUREAU OF ECONOMIC RESEARCH \\ 1050 Massachusetts Avenue \\ Cambridge, MA 02138 \\ July 1996
}

This research was supported in part by the National Science Foundation and by the National Bureau of Economic Research. This is a revision of a September, 1995 paper with the same name. I am indebted to the management at Safelite Glass Corporation for providing the data on which the empirical analysis is based. Excellent comments by Michael Schwarz and Eric Stout are gratefully acknowledged. This paper is part of NBER's research programs in Labor Studies and Productivity. Any opinions expressed are those of the author and not those of the National Bureau of Economic Research.

(C) 1996 by Edward P. Lazear. All rights reserved. Short sections of text, not to exceed two paragraphs, may be quoted without explicit permission provided that full credit, including $\odot$ notice, is given to the source. 


\title{
PERFORMANCE PAY AND PRODUCTIVITY
}

\begin{abstract}
What happens when a firm switches from paying hourly wages to paying piece rates? The theory developed below predicts that average productivity rises, that the firm will attract a more able work force and that the variance in output across individuals at the firm will rise as well. The theory is tested with data from a large autoglass company that changed compensation structures between 1994 and 1995. All theoretical predictions are borne out. In the firm examined, the productivity effects are extremely large, amounting to anywhere from about $20 \%$ to $36 \%$ of output, depending on what is held constant. About half of the worker-specific increase in productivity is passed on to workers in the form of higher wages.
\end{abstract}

Edward P. Lazear

Graduate School of Business

Stanford University

Stanford, CA 94305-5015

and NBER 
Many believe that an easy way to increase productivity in an organization is to pay on the basis of measured performance. Of course, there are some difficulties associated with performance pay schemes that have been pointed out in the literature. ${ }^{1}$ There have been few attempts to examine the choice of payment scheme and its effect on output. ${ }^{2}$ In large part, the lack of literature is a direct result of a lack of data. It is difficult to find situations where some workers are paid on the basis of performance and other workers are paid according to some other scheme, coupled with the condition that the comparisons do not also involve a number of other factors that vary across the groups. The analysis in this paper does not suffer from the traditional problem. It is based on data from a large autoglass company named Safelite Glass Corporation. During 1994 and 1995, after the introduction of new management, the company gradually changed the compensation method for its work force, moving them from hourly wages to piece rate pay. The effects, which are documented below, were dramatic and completely in line with economic theory.

In what follows, the theory of piece rate compensation is sketched with particular emphasis on the predictions that pertain to changes in the compensation method. The theory is backed up by the empirical results, the most important of which are:

1. A switch to piece rate pay has a significant effect on average levels of output. This is in the range of a $36 \%$ gain.

'See Lazear (1986) for a detailed discussion of when to pay a piece rate, which is defined to be payment on the basis of output. Also, Fama (1991) discusses other reasons for paying on the basis of some measured time interval. Baker (1992) discusses the difficulties created by pay-for-performance structures when measurement is a problem. A very early discussion of the incentive effects of piece rates can be found in Slichter (1928), Ch. 13.

${ }^{2}$ A notable exception is Brown (1992). Some have looked at the effects of compensation in the sports world. Most recently, Fernie and Metcalf (1996) find that when payment is contingent on performance, jockeys better performance than when payment is unrelated to performance. Also, Parsch and Shearer (1996) find that tree planters in British Columbia produce higher levels of output when paid on piece rate, but that they fatigue more rapidly. 
2. The gain can be split into two components. More than half of the increase in productivity results from the average worker producing more because of incentive effects. Some results from a reduction in tumover among the most productive workers and an ability to hire the most productive workers. None reflects the "Hawthorne effect."

3. Productivity gains show up in a number of ways. In addition to an increase in the number of pieces produced in a given day and altering turnover, moving to pay for performance implies reductions in absenteeism.

4. The firm shares the gains in productivity with its workforce. For a given worker, about half of the worker-specific increased productivity is captured by the worker.

5. Moving to piece rate pay increases the variance in output. More ambitious workers have less incentive to differentiate themselves when hourly wages are paid than when piece rate pay is used. Also, the variance in underlying ability rises because the most able workers are attracted by the piece rate.

The evidence implies that the choice of compensation method is important, not that piece rates are good. In equilibrium, firms choose a compensation method, based on the costs and benefits of the various schemes. Firms that continue to pay hourly wages must, in equilibrium, find that benefits of paying an hourly wage, such as low monitoring costs and perhaps higher quality output, outweigh the costs in the form of lower output.

Some conclusions are unambiguous. Workers respond to prices just as economic theory predicts. Claims by sociologists and others that monetizing incentives may actually reduce output are unambiguously refuted by the data. Not only do the effects back up economic predictions, but the effects are extremely large and precisely in line with theory. 
The evidence allows somewhat broader interpretation. It is often difficult to obtain actual data on consumers and their reactions to changes in prices. Tests of even the most basic tenets of economic theory are difficult to perform, at least at a micro level. These data are well-suited to that purpose. While experiments bear out the basic response of economic agents to prices, the data used in this paper come from the real world, rather than a laboratory setting. Compensation, which reflects the most important price that a consumer faces, truly matters to the workers in this setting, and they respond accordingly.

\section{Modeling Choice of Pay Scheme: Hourly Wages versus Piece Rates}

The primary motivation behind instituting a piece rate scheme is to increase worker effort. While it may seem obvious that moving from hourly wages to piece rates would increase effort, it is not. When a firm institutes an hourly wage schedule, it usually couples the payment with some minimum level of output that is acceptable. It is possible, therefore, that the minimum acceptable output chosen for hourly wage workers exceeds the level of output that workers voluntarily choose under a piece rate. Further, it may be that the minimum level chosen under hourly wages is so high that only the most able workers can make the cut. When piece rates are instituted, more heterogeneity might be tolerated, resulting in lower average levels of output.

In some sense, the term "performance pay" is not very useful. Even if we restrict performance pay to refer to pay based on output (rather than input), a broad set of compensation schemes are included. Hourly wages that are coupled with some minimum standard could be called performance pay, because a performance standard must be met to retain employment. In fact, were workers homogeneous, an hourly wage structure with a minimum number of units tolerated per hour can 
achieve the efficient outcome. ${ }^{3}$

Given that workers differ in their talent, ambition, or willingness to trade time for money, it is necessary to derive the optimal minimum standard under hourly wages in a more general context. The resulting levels of output and the distribution of worker abilities is then compared with that which is expected to result under the piece rate scheme that was chosen by Safelite.

Begin, then, by defining $e$ to be the output level chosen by a worker, which is a function of underlying ability, $A$, and of effort choice. Let $A \sim g(A)$ with distribution function $G(A)$. The activity in question in the empirically analysis, specifically, the installation of glass into automobiles, is easily monitored. Thus, suppose that the firm can observe $e$.

\section{Hourly Wages}

The firm that pays an hourly wage can specify some minimally acceptable level of output per hour $e_{0}$. The firm fires workers whose output falls consistently below $e_{0}$. Commensurate with that level of required output is some wage, $W$, that the firm offers. The worker's utility function is given by

$$
\text { Utility }=\text { Income }-\frac{C(e)}{A}
$$

where $C(e)$ is the homogeneous part of the cost function with $C^{\prime}, C^{\prime \prime}>0$. Since $A$ measures ability, individuals with higher levels of ability have lower costs of producing any given level of output, $e .^{4}$

\footnotetext{
${ }^{3}$ To do this, simply solve for the efficient level of effort per hour which sets the marginal cost of effort equal to the marginal value of effort. Require that level of effort as the minimum standard for the job. Then, set the hourly wage just high enough to attract workers to the firm.

${ }^{4}$ The words " output" and "effort are used interchangeably. It is always possible to redefine $C(e)$ such that one unit of effort, say measured in calories burned, produces one unit of output.
} 
As mentioned above, were workers homogeneous and output or effort observable, it would be straightforward to implement the efficient level of effort using hourly wages and an output requirement. Given the utility function in (1), the efficient level of output is $e^{*}$, such that

$$
C^{\prime}\left(e^{*}\right) / A=1
$$

because the marginal value of a unit of output is normalized to be 1 . The firm could simply require that workers produce at least $e^{*}$. Then the firm would set the wage, $W$, such that

$$
W=C\left(e^{*}\right) / A
$$

so that workers would be willing to work.

Workers are heterogeneous and this makes the problem more difficult for the firm. The problem is that the standard and wage that is right for one group of workers is not right for another group. Thus, the firm must choose a standard and wage that is the best compromise. The problem is solved as follows:

For any given pair of required output and wage, $\left(e_{0}, W\right)$, there is a group of workers who will accept the job. Specifically, only those with sufficiently high ability such that

$$
W \geq C\left(e_{0}\right) / A
$$

accept the job. The minimum ability individual who will accept a job that requires $e_{0}$ of output to be produced is $\mathrm{A}_{0}$ such that

(2) $W=C\left(e_{0}\right) / A_{0}$.

Suppose that the firm receives a given number of job applications in any period. Then the firm wants to maximize expected profits, taking into account that a high wage is more likely to attract workers, but that a low wage yields higher profit on any given worker. It is not obvious that effort 
is low in an hourly wage firm because it is possible that the firm may choose to specify a level of $e_{0}$ that exceeds the level chosen in the piece rate problem. Of course, requiring a higher $e_{0}$ implies that the firm must pay a higher $W$ to attract any given worker.

All workers with ability levels that exceed $A_{0}$ earn rents because they are required only to produce $e_{0}$ of output and the pain associated with producing it is lower than the pain for individuals with ability $A_{0}$, who are just indifferent between working and not. However, because there is competition from other firms in this industry and others, a worker must compare the rents earned at this firm with those earned elsewhere.

Define $R(A)$ as the rent that a worker of ability $A$ can expect to receive elsewhere, with $R^{\prime}(A)>0$ because higher ability workers can always do what a lower ability worker can do elsewhere and do it with less pain. Thus, workers who have $R(A)>W-C\left(e_{0}\right) / A$ will choose to work elsewhere. Thus, for any wage policy $W$ and work requirement $e_{0}$, there is a group of workers who will work at the firm. Since all receive the same wage, all choose to produce at the minimum level of output, $e_{0}$. Those willing to work have ability greater than $A_{0}$, but less than $A_{h}$, where $A_{h}$ solves

$$
W-C\left(e_{o}\right) / A_{h}=R\left(A_{h}\right)
$$

This situation is illustrated in figure 1. 


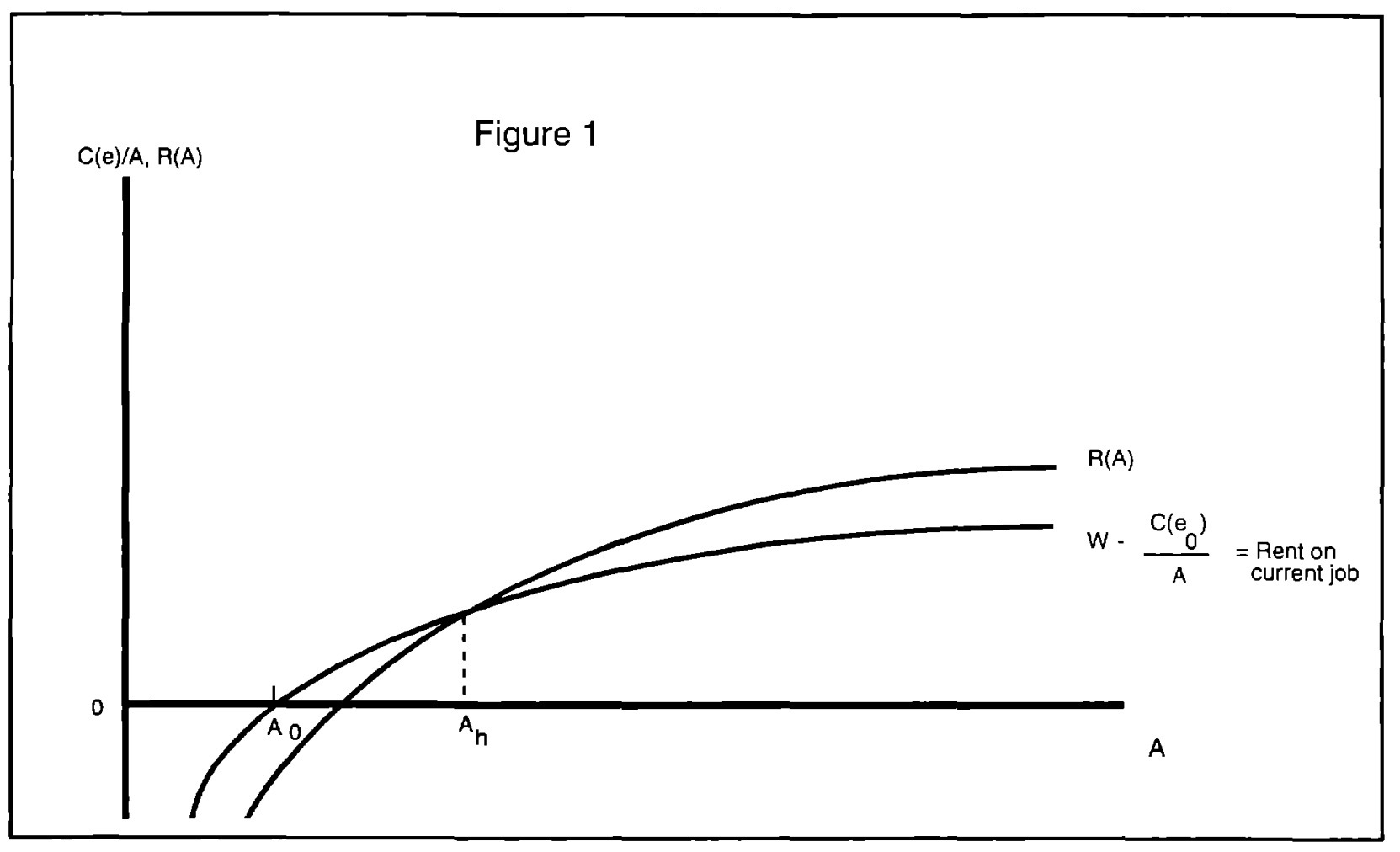

Ability is shown on the horizontal axix. As rises, $W-C\left(e_{0}\right) / A$ rises because higher ability individuals produce output $e_{0}$ at less cost. Both $A_{0}$ and $A_{h}$ are defined as in (2) and (3), respectively. In fig. $1, R(A)$ is shown to cross $W-C\left(e_{0}\right) / A$. This is reasonable since more able workers do not earn higher wages under the straight hourly wage scheme. Every worker earns Wand produces $e_{0}$. The only reason that rents are higher on the current job for higher ability workers is that the more able accomplish the task more easily. But other firms need not constrain all workers to earn the same amount. It is for this reason that $R(A)$ is steeper than $W-C\left(e_{0}\right) / A$. (It is possible, however, that $R(A)$ would never cross $W-C\left(e_{0}\right) / A$. If opportunities outside are sufficiently bad, all workers with $A>A_{0}$ would work at this firm and $A_{h}=\infty$ ). All workers with ability $A$, such that 
$A_{0}<A<A_{h}$

choose to work at the firm. ${ }^{5}$

The problem for the firm is to choose $W$ and $e_{0}$. The firm wants to choose a lower $W$ for any given level of output, but this will affect the number of individuals who are willing to work on this job. Similarly, the firm would like to set the minimum output standard as high as possible. But for any given $W$, higher required levels of output mean that fewer workers are willing to take the job.

The maximization problem for the firm can be written formally as

$$
\text { (4) } \underset{e_{0}, W}{\operatorname{Max}} \int_{A_{0}}\left(e_{0}-W\right) g(A) d A
$$

where $A_{0}$ and $A_{h}$ are given by (2) and (3). Once $A_{0}$ and $e_{0}$ are selected, $W$ is determined by (2), and $A_{h}$ is determined according to (3). Thus, substituting (2) into (4), and integrating allows (4) to be rewritten as

$$
\underset{e_{0}, A_{0}}{\operatorname{Max}}\left[e_{0}-\frac{C\left(e_{0}\right)}{A_{0}}\right]\left[G\left(A_{h}\right)-G\left(A_{0}\right)\right]
$$

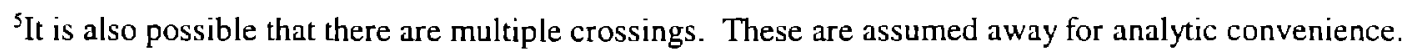


which has first order conditions

$$
\frac{\partial}{\partial e_{0}}=\left(1-\frac{c^{\prime}\left(e_{0}\right)}{A_{0}}\right)\left[G\left(A_{h}\right)-G\left(A_{0}\right)\right]+\left[e_{0}-\frac{C\left(e_{0}\right)}{A_{0}}\right] g\left(A_{h}\right) \frac{\partial A_{h}}{\partial e_{0}}=0
$$

and

$$
\frac{\partial}{\partial A_{0}}=\left[G\left(A_{h}\right)-G\left(A_{0}\right)\right] \frac{C\left(e_{0}\right)}{A_{0}^{2}}+\left(e_{0}-\frac{C\left(e_{0}\right)}{A_{0}}\right)\left[g\left(A_{h}\right) \frac{\partial A_{h}}{\partial A_{0}}-g\left(A_{0}\right)\right]=0
$$

where $\frac{\partial A_{h}}{\partial e_{0}}$ and $\frac{\partial A_{h}}{\partial A_{0}}$ are derived from (2) and (3).

From (2) and (4), it is clear that $e_{0}>C\left(e_{0}\right) / A_{0}$ in order for the firm to make positive profits. Using (6a) and the fact that $\partial A_{h} / \partial e_{0}>0, C^{\prime}\left(e_{0}\right) / A_{0}>1 .{ }^{6}$ The lowest quality worker is forced to produce more then the efficient amount of output because the firm cannot discriminate between low and high ability workers. In its attempt to set a standard high enough for the high ability workers, it must force the low ability worker to work harder than they would optimally work. It is also true

$$
\text { 6Using (2), (3) and the implicit function theorem, } \quad \frac{\partial A_{h}}{\partial e_{0}}=\frac{C^{\prime}\left(e_{0}\right)\left(\frac{1}{A_{h}}-\frac{1}{A_{0}}\right)}{C \frac{\left(e_{0}\right)}{A_{h}{ }^{2}}-R^{\prime}\left(A_{h}\right)}>0 \quad \text { because the }
$$

numerator is negative and the denominator is negative. The denominator is negative because the slope of $R(A)$ is greater than that of $W-C\left(e_{0}\right) / A$ at $A=A_{h}$ (see figure 1). 
that high ability workers put forth too low an effort level. ${ }^{7}$ The choice of $\left(e_{0}, W\right)$ is a compromise.

It is the correct choice for almost no specific worker type. Output $e_{0}$ is to high for $A_{0}$ and too low for $A_{h}$. Recognition of this problem pushes firms in the direction of performance pay. Performance pay allows better adjustment for worker heterogeneity. Those who want to put forth higher levels of effort receive higher compensation.

A linear piece rate takes the form $(b e-K)$ so the utility that a risk neutral worker receives can be written

(7) Utility under piece rate $=$ be $-K-\frac{C(e)}{A}$

The worker maximizes (7) by choosing $e$, which has first-order condition

(8) $\quad \frac{C^{\prime}(e)}{A}=b$.

Define $e_{0}^{*}$ as the level of output chosen by the lowest ability worker, $A_{0} *$, who chooses to work.

Given (8), $e_{0} *$ is the solution to

${ }^{7}$ The analysis is tedious, but similar to that given in the previous text and footnote. The logic is that if even the highest ability worker were producing above his optimal level of effort, $W$ could be reduced by more than the lost output to make both worker and firm better off. But if reducing $e_{o}$ and $W$ is viable for the most able worker, it is even more beneficial to lower ability workers, for whom higher standards impose even greater costs. 


$$
C^{\prime}\left(e_{0}^{*}\right) / A_{0}^{*}=b
$$

Similarly, define $\mathrm{e}_{\mathrm{h}}{ }^{*}$ as the output level chosen by the highest ability worker, $A_{h}{ }^{*}$, who chooses to work. Given (8), $\mathrm{e}_{\mathrm{h}}{ }^{*}$ is the solution to

$$
C^{\prime}\left(e_{h}^{*}\right) / A_{h}^{*}=b .
$$

In order to fit the Safelite situation analyzed in the empirical section below, it is useful to model the effects of switching from an hourly wage with minimum standard to a piece rate with a minimum guarantee. As part of Safelite's plan, it offered a guarantee at approximately the former wage. The guarantee was coupled, presumably, with the same minimum standard of $e_{0}$ as before.

Thus, the plan paid $W$ to anyone who would have earned less than $W$ under the piece rate, but paid the piece rate to all of those whose compensation by the piece rate formula would have exceeded W. The scheme used is

$$
\text { Compensation }=\max [W, b e-K] .
$$

The situation is shown in figure 2 . 


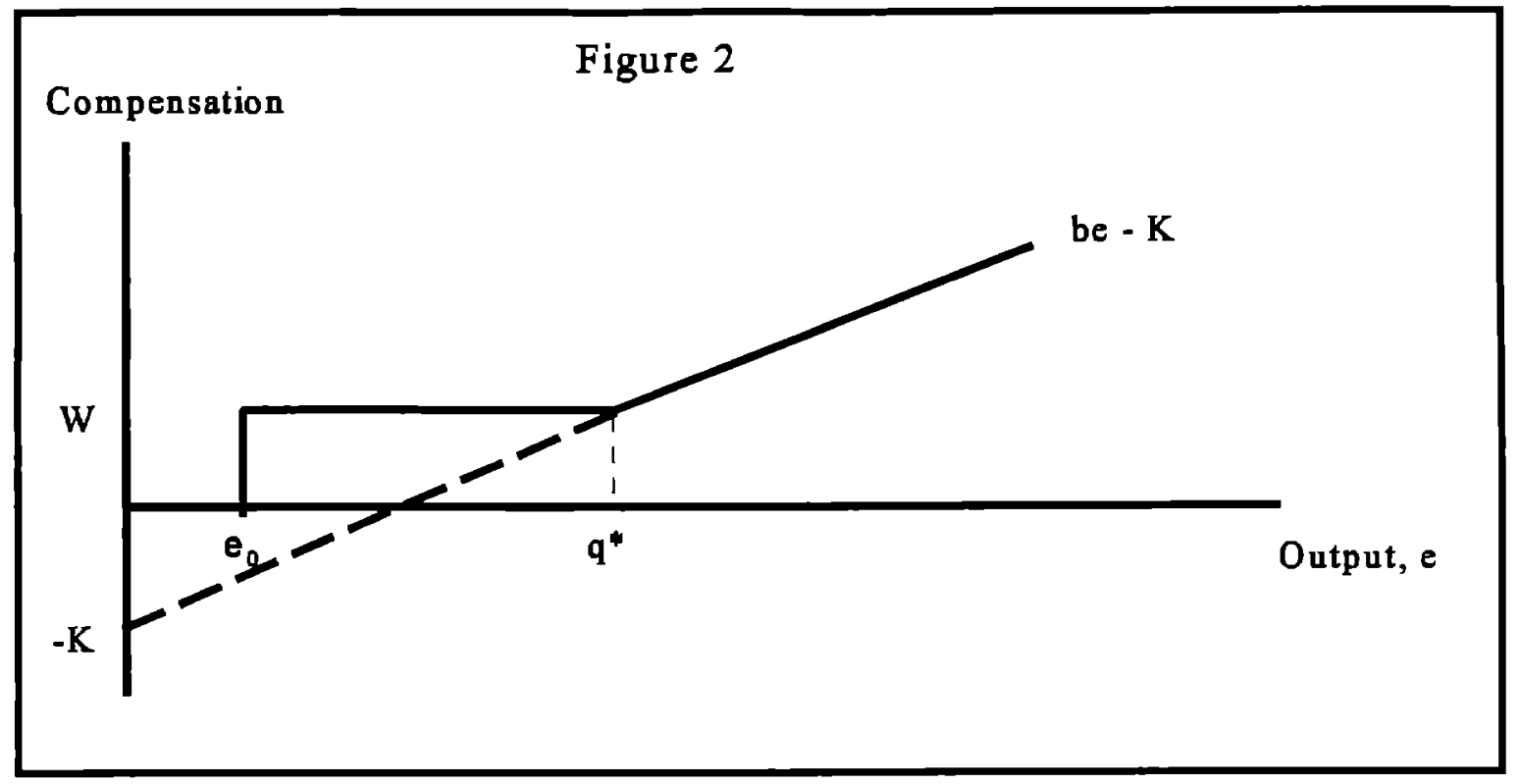

This scheme is typical of many salespersons' plans. A draw, in this case equal to W, is paid

up to some level of output. Until that target level is reached, the worker receives only $W$. After $q^{*}$, he begins to receive additional compensation for increases in output. Of course, this scheme charges all workers whose output exceeds $W$ the amount $K$ for the job. As long as the worker produces $q>q^{*}$, his compensation is given by $b e-K$. At most firms, workers who continually dip into their draw by producing $q<q^{*}$ are likely to find their employment terminated after some period of time.

It is now possible to state proposition 1.

Proposition 1: Effort is does not decrease when the firm switches from hourly wages to piece rates, and for high enough values of $b$, effort increases.

Proof: Output cannot fall below $e_{0}$ because of the firm imposed constraint at $e_{0}$. But output may exceed $e_{0}$ if for some $A, A_{0} \leq A \leq A_{h}$, 
(P1.1)

$$
W-C\left(e_{0}\right) / A<b e *(A)-K-C(e *(A)) / A
$$

Then the worker of type $A$ prefers to work above the level given by the guarantee. Since all workers worked at level $e_{0}$ under hourly wages, output rises with piece rates for $b$ sufficiently high to guarantee that condition (P1.1) holds for some $A$. III

Because the guarantee binds for some workers, but not for all, effort does not increase for all workers. Workers whose optimal level of effort by (8) lies to the left of $q^{*}$ in fig. 2 gain nothing by increasing effort. But those whose optimal level of effort is sufficiently high may choose to work enough to be on the upward sloping portion of the compensation function.

It is now possible to determine which type of worker is willing to work for the firm under the new compensation scheme. Recall that $A_{0}$ and $A_{h}$ were the lower and upper cutoffs of workers under the hourly wage. Define the lower and upper cutoffs in the new regime as $A_{0}{ }^{*}$ and $A_{h} *$, respectively.

Let us examine the relation of $A_{0} *$ to $A_{0}$ and of $A_{h} *$ to $A_{h}$. First note that $A_{0} *=A_{0}$ if

$$
b e_{0} *-K-C\left(e_{0} *\right) / A_{0}<W-C\left(e_{0}\right) / A_{0}
$$

here $e_{0} *$ was defined above as the optimal output for type $A_{0}$ under piece rates.

When (12) holds, all $A_{0}$ types prefer to accept the guaranteed wage of $W$ and to work at $e_{0}$. Nothing is changed for the lowest ability individual. Since types $A_{0}$ do not take advantage of piece rates, no one with $A<A_{0}$ will take advantage of piece rates so the bottom cutoff remains unchanged. ${ }^{8}$

'It must be true that if $A_{0}$ accepts the guarantee of $W$, then anyone with $A<A_{0}$ accepts the guarantee as well. But $A_{0}$ is defined as the lowest type to accept the cutoff. 
Conversely, if (12) does not hold, then $A_{0}$ strictly prefers the piece rate which means that rents are positive for $A_{0}$ types. This implies that there exists $A<A_{0}$ for whom rents are zero. But $A_{0} *$ is defined as the (new) type who earns zero rents at the job. Thus, when condition (12) does not hold, $A_{0} *<A_{0}$.

Also, if

$$
b e_{h} *-K-C\left(e_{h}^{*}\right) / A_{h}>W-C\left(e_{0}\right) / A_{h},
$$

(where $e_{h} *$ was defined as the optimal output for type $A_{h}$ under piece rates)

then $A_{h} *>A_{h}$.

When condition (13) holds, the highest ability type under the hourly wage shuns the guarantee in favor of higher effort, higher earnings piece rates. This implies that $A_{h}$ now earns rents and can no longer be the marginal worker. Then there must exist an $A>A_{h}$ who is willing to work at the firm as well. Thus, $A_{h} *>A_{h}$.

It is now possible to state the following proposition:

Proposition 2: A sufficient condition for the average ability of the work force to rise after the switch to piece rates is that some workers accept the guaranteed wage and some workers choose to work enough to be on the piece rate. In terms of figure 2 , as long as there are workers whose output lies on both sides of $q^{*}$, average ability rises.

Proof: 
If any accept the wage guarantee, then surely $A_{0}$ accepts the guarantee. We know that $A_{0}$ is willing to work for $W$ at effort $e_{0}$ because $A_{0}$ worked under these terms before. Furthermore, since the guarantee has not been made any more attractive, no one with $A<A_{0}$ is willing to work.

But this means that condition (12) must hold, so $A_{0} *=A_{0}$.

Conversely, if any choose to work in the piece rate range, then surely the worker with the highest ability chooses to work in this range. But the highest ability worker cannot be $A_{h}$. If $A_{h}$ chooses to work in the piece rate range, then condition (13) holds, which implies that $A_{h} *>A_{h}$.

It is possible, that $A_{h}$ chooses to accept the wage guarantee and another worker chooses to work in the piece rate range. But that worker must have $A>A_{h}$ or $A_{h}$ would prefer the piece rate as well. In this case $A_{h}>A_{h} *$. Since $A_{0} *=A_{0}$, and since $A_{h} *>A_{h}$, average ability must rise. III Average ability rises because the ability of the lowest quality worker does not change as a result of the switch in compensation scheme, but the average ability of the highest quality worker rises. Because a piece rate allows the more able to work harder and receive more from the job, and because the hourly wage does not, more able workers prefer piece rates. The least able worker is indifferent between the two schemes. Switching to piece rates has the effect of improving retention and recruitment of high quality workers. ${ }^{9}$

Proposition 3: A sufficient condition for the variance of worker ability and output to rise after the

The condition that some workers continue to opt for the guaranteed wage is not superfluous. Were all workers to opt for the piece rate, then it is possible that even very low ability workers who did not work before now work for the firm. Their addition could actually result in a lowering of average quality. 
switch to piece rates is that some workers accept the guaranteed wage and some workers choose to work enough to be on the piece rate.

Proof:

From the proof to proposition $2, A_{0} *=A_{0}$ and $A_{h} *>A_{h}$. This is sufficient to imply that variance in ability rises. Also, since all workers choose to produce $e_{0}$ under the hourly wage, but workers who work on piece rates chooses e according to (8) under a piece rate, positive variance in $A$ implies positive variance in e under piece rates. III

Even if underlying ability levels did not change, variance in productivity would rise because workers choose the same level of output under an hourly wage, but type-specific levels of output under piece rates. When it is recognized that the maximum ability level increases under a piece rate, the change in output variance becomes even greater.

\section{Data:}

Safelite Glass Corporation is located in Columbus Ohio and is the country's largest installer of automobile glass. Recently, Safelite, under the direction of CEO, Garen Staglin, and President, John Barlow, instituted a new compensation scheme for the autoglass installers. Until January, 1994, glass installers were paid an hourly wage rate, which did not vary in any direct way with the number of windows that were installed. During 1994 and 1995, installers were shifted from an hourly wage schedule to performance pay - specifically, to a piece rate schedule. Rather than being paid for the number of hours that they worked, installers were now paid for the number of glass units that they installed. The rates varied somewhat, on average installers were paid $\$ 20$ per unit installed. At the time that the piece rates were instituted, the workers were also given a guarantee of approximately 
$\$ 11$ per hour. If their weekly pay came out to less than the guarantee, they would be paid the guaranteed amount. Many workers ended up in the guarantee range.

Safelite has a very sophisticated computerized information system, which keeps track of how many units of each kind that each installer in the company installed in a given week. For the purposes here, monthly data were used. Since PPP (performance pay plan) was phased in over the 18 month period, most workers were employed under both regimes. Thus, data on individual output are available for most installers both during the hourly wage period and during the PPP period. This before-and-after comparison with person specific data provides a very clean body of information on which to base an analysis of performance pay.

Some basic characteristics of the sample are reported in table 1. The data are organized as follows. Each month provides an independent unit of observation. There are 38,764 person months of data covering a 19 month period. Thus, there are $38764 / 19$ or 2040 workers employed during the average month. Over the 19 month period, there was a total of 3707 different individuals who worked for Safelite as installers, called "associates." The number of "good" observations is 31,104 when partial months are dropped from the data set.

There are a number of possible productivity measures. The one that most Safelite managers look to is UAD, or units-per-associate-per-day. This is the total number of glass units per 8 hour day that are installed by a given associate. The UAD number for each individual observation relates to a given associate in a given month. Thus, UAD is the average number of units per 8 hour period installed by the given associate during the given month.

The average number of glass units installed per day over the entire period is 2.96 , with a standard deviation of 1.53. Under the PPP formula, the average worker would have earned $\$ 1711$ 
if only the PPP formula were used. In actuality, the average actual pay was $\$ 2250$. The difference reflects vacation, holiday and sick pay, as well as two other factors. First, not all workers are on PPP during the period. When on hourly wages, some received higher compensation than they would have had they been on PPP, given the number of units installed. Of course, when a given worker switches to PPP, incentives change and his output may go up enough to cover the deficit. Second, even when workers are on PPP, a substantial fraction of person weeks calculated on the basis of the PPP formula come in below the guaranteed weekly compensation. The guarantee binds for those worker weeks and actual pay then exceeds PPP pay. In all months after the introduction of PPP, at least some workers received the guaranteed pay and some earned more than the guarantee. Thus, the sufficient conditions for propositions 2 and 3 are met throughout the period. 
Table 1

Data Description

\begin{tabular}{|c|c|c|c|}
\hline Variable & Definition & Mean & $\begin{array}{l}\text { Std. } \\
\text { Deviation }\end{array}$ \\
\hline PPPFLAG & $\begin{array}{l}\text { a dummy variable equal to } 1 \text { if the worker is } \\
\text { on PPP during that month }\end{array}$ & 0.53 & \\
\hline BASERATE & Hourly wage & $\$ 11.47$ & $\$ 2.95$ \\
\hline UAD & $\begin{array}{l}\text { Units per associate per day. Average number } \\
\text { of units of glass installed by the given } \\
\text { associate during the month in question. }\end{array}$ & 2.96 & 1.53 \\
\hline REGHOURS & Regular hours worked & 153 & 40 \\
\hline OVTHRS & Overtime hours worked & 19 & 19 \\
\hline SICKHRS & Number of hours of paid sick time & 0.4 & 2.62 \\
\hline SICKPAY & Average amount paid in sick benefits & $\$ 5.38$ & $\$ 36.67$ \\
\hline ACTPAY & Pay actually received in a given month & $\$ 2250$ & $\$ 883$ \\
\hline PPPPAY & $\begin{array}{l}\text { Pay earned by the straight PPP formula; if } \\
\text { there were no guaranteed wage, this, plus } \\
\text { compensation for non-worked time, would } \\
\text { equal actual pay for those person-months with } \\
\text { PPPFLAG=1 }\end{array}$ & $\$ 1711$ & $\$ 928$ \\
\hline PAYPRDAY & $\begin{array}{l}\text { Pay-per-day: Actual pay per eight hours } \\
\text { worked }=\mathrm{t}\end{array}$ & $\$ 106$ & $\$ 36$ \\
\hline CSTPU & $\begin{array}{l}\text { Cost-per-unit: ACTPAY for a given worker, } \\
\text { divided by the number of units installed by } \\
\text { that worker in a given month }\end{array}$ & $\$ 40$ & $\$ 62$ \\
\hline LNPAYDAY & Log (PAYPRDAY) & 4.62 & 0.29 \\
\hline SEPAR & $\begin{array}{l}\text { Dummy = } 1 \text { if the employee quit during this } \\
\text { month. }\end{array}$ & .035 & \\
\hline \multicolumn{4}{|c|}{$\begin{array}{l}\text { There were } 3707 \text { individuals who worked as installers over the } 19 \text { month period covered } \\
\text { by the data. The unit of analysis is a person-month. There are } 31,104 \text { person-months of } \\
\text { good data. PAYPRDAY is calculated only for workers whose total hours in a month } \\
\text { exceeded } 10 \text { and CSTPU only for workers whose monthly units installed exceeded } 3 .\end{array}$} \\
\hline
\end{tabular}


Means for actual and PPP pay reveal almost nothing about the effects of PPP on performance and sorting. A more direct approach is needed. Table 2 presents some means of the key variables and breaks them down by PPPFLAG, a dummy set equal to 1 if the worker in question is on PPP during the given month. ${ }^{10}$

Table 2

Means of Key Variables by Pay Structure

\begin{tabular}{|c|c|c|c|c|}
\hline & \multicolumn{2}{|c|}{ PPPFLAG=0 (Hourly Wages) } & \multicolumn{2}{|c|}{ PPPFLAG=1 (Piece rates) } \\
\hline Number of Obs. & 13850 & & 15,691 & \\
\hline Variable & Mean & Std. Deviation & Mean & Std. Deviation \\
\hline $\mathrm{UAD}$ & 2.69 & 1.41 & 3.23 & 1.58 \\
\hline SICKHRS & 0.60 & 3.0 & 0.25 & 1.98 \\
\hline ACTPAY & $\$ 2226$ & $\$ 800$ & $\$ 2279$ & $\$ 951$ \\
\hline PPPPAY & $\$ 1575$ & $\$ 822$ & $\$ 1841$ & $\$ 998$ \\
\hline CSTPU & $\$ 44.48$ & $\$ 74.95$ & $\$ 35.23$ & $\$ 48.56$ \\
\hline
\end{tabular}

Note: 1563 observations were dropped because the individual spent part of the month on PPP and part on hourly wages.

The story that will be told in more detail below shows up in the simple means. The average level of UAD is about .54 units, or $20 \%$ higher in the piece rate regime than in the hourly wage regime. Also, the variance in output goes up when switching from hourly wages to piece rates, as can be seen by comparing the standard deviations of 1.58 to 1.41 . Thus, propositions 1,2 and 3 , which state that both mean and variance in output rise when switching from hourly wages to piece rates are borne out by the simple statistics. Further, note that there is a good indication that profitability went up significantly with the switch. The cost per unit is considerably lower in the piece

\footnotetext{
${ }^{10}$ Only observations where workers were on one pay regime or the other for the full month are used. Partial month observations are deleted.
} 
rate regime than it is with hourly wages. ${ }^{11}$

The simple statistics do not take other factors into account. In particular, autoglass demand is closely related to miles driven, which varies with weather. Major storms also cause glass damage. Month effects and year effects matter. Perhaps more important, the management change that took place before PPP was instituted had other direct effects on the company as well that may have changed output during the sample period, irrespective of the switch to PPP. To deal with these factors, row 1 of table 3 reports the coefficients from a regression of the log of UAD month and year dummies. The coefficient on PPPFLAG is .36 , indicating that there is a $36 \%$ gain in productivity as measured by UAD associated with a move to PPP.

There are three possible interpretations of this extremely large and statistically precise effect. First, the gain in productivity may result from incentive effects associated with the program. Second, the gain may result from sorting. A different group of workers may be present after the switch to piece rates. Third, the pattern of implementation may cause a spurious positive effect. Suppose that Safelite picked its best workers to put on piece rates first. The PPPFLAG coefficient would pick up an ability effect because high ability workers would have more PPP months than low ability workers. These three effects can all be identified by using the data in a variety of ways.

\footnotetext{
"The fact that actual pay has only risen slightly after the switch to PPP than before reflects the phase in pattern of the PPP program. Lower wage areas were brought into the program first, which means that the PPP=1 data are dominated by lower wage markets.
} 
Table 3

Regression Results

Dependent Variable: In (UAD) Independent Variable: PPPFLAG plus dummies Number of Observations: 31,104

\begin{tabular}{|l|l|l|l|l|l|}
\hline $\begin{array}{l}\text { Reg. } \\
\#\end{array}$ & $\begin{array}{l}\text { Coeff. on } \\
\text { PPPFLAG }\end{array}$ & $\begin{array}{l}\text { Coeff. } \\
\text { on TENUR }\end{array}$ & $\begin{array}{l}\text { Coeff. } \\
\text { on } \\
\text { PPPTENUR }\end{array}$ & $\begin{array}{l}\mathrm{r}- \\
\text { sqr. }\end{array}$ & Description \\
\hline 1 & $\begin{array}{l}.36 \\
.01)\end{array}$ & & .04 & $\begin{array}{l}\text { Dummies for month and year } \\
\text { included }\end{array}$ \\
\hline 2 & $\begin{array}{l}.20 \\
.01)\end{array}$ & & .76 & $\begin{array}{l}\text { Dummies for month and year; } \\
\text { worker specific dummies included } \\
(3181 \text { individual workers })\end{array}$ \\
\hline 3 & $\begin{array}{l}.29 \\
.01)\end{array}$ & $\begin{array}{l}.10 \\
(.02)\end{array}$ & $\begin{array}{l}.26 \\
(.02)\end{array}$ & .04 & $\begin{array}{l}\text { Dummies for month and year } \\
\text { included. }\end{array}$ \\
\hline
\end{tabular}

Standard errors are reported in parentheses below the coefficients.

Regression 1 has a coefficient on PPPFLAG of .36. When worker dummies are included, the coefficient drops to .20 . Still, .20 is a huge number and is the pure incentive effect that results from switching from hourly wages to piece rates. A given worker installs $20 \%$ more units after the switch to PPP than he did before the switch to PPP. This estimate controls for month and year effects. There is no interpretation of the PPPFLAG coefficient in regression 2 other than the incentive one. Individual ability is held constant as is location by including the person dummies. Approximately 5/9 of the $36 \%$ difference in productivity attributed to the PPP program reflects an incentive effect.

Nor does this gain appear to be a "Hawthorne effect." 12 This can be seen by examining regression 3 in table 3. The variable, "TENUR", is not actual years of tenure in the firm because the true start date is unavailable. But TENUR does measure the passage of time in the firm. Specifically, it is defined as the time since either the beginning of the sample period, i.e., January, 1994, or the

\footnotetext{
${ }^{12}$ The Hawthorne effect, which many now dispute, alleges that any change is likely to bring about short term gains in productivity.
} 
worker's start date, whichever is later. Thus, if the worker had started sometime before January, 1994, tenure in July, 1994 would be .5. If the worker had started in April, 1994, then tenure in July, 1994 would be .25 . The coefficient on TENUR differs from true tenure effects only to the extent that nonlinearities are important. The variable, "PPPTENUR" is defined as the number of years since the worker was switched from hourly wage to piece rate, times PPPFLAG. For example, a worker who started 1994 on hourly wages and was switched to PPP on July 1, 1994 would have PPPTENUR=0 for the June, 1994 observation, .5 for the January, 1995 observation, and 1.0 for the June, 1995 observation.

Tenure effects are large and significant. One year of experience raises productivity by about $10 \%{ }^{13}$ More interesting, perhaps, is the effect of time on the PPP program. The coefficient of .26 on PPPTENUR, coupled with a PPPFLAG coefficient of .29 , means that the initial effect of switching from hourly wage to piece rate is to increase productivity by $29 \%$. After one year on the program, the increase in productivity has grown to $.29+.26$ or $55 \%$. The Hawthorne effect would imply a negative coefficient on PPPTENUR. If the Hawthorne effect held, then the longer the worker were on the program, the smaller would be the effect of piece rates on productivity. The reverse happens here. After workers are switched to piece rates, they seem to learn ways to work faster or harder as time progresses. ${ }^{I 4}$

${ }^{13}$ Note that these estimates do not take out person effects so a significant part of the effect probably reflects sorting. Those who are not making it get fired or quite. It is impossible to hold month, year, and tenure effects constant and to allow for individual effects since the individual dummy would remove any effect of start date.

${ }^{14}$ An alternative is that the sorting effects mentioned in the previous footnote become more pronounced under a piece rate system and that PPPTENUR reflects the differential sorting rate under the PPP program. 


\section{Sorting:}

The theory stated in propositions 2 and 3 suggests that the optimal piece rate is implemented such that both mean and variance of worker ability should rise after the switch to piece rates. The theory implies specifically that there should be no change in the number of low ability workers who are willing to work with the firm, but that piece rates would allow high ability workers to use their talents more lucratively. Thus, the top tail of the distribution should thicken.

Underlying ability is difficult to measure, but actual output can be observed. Suppose that workers must try the job for awhile to discover their ability levels. Workers who find the job unsuitable leave. Thus, looking at the relation of ability to separation rates before and after the switch to piece rates will provide evidence on the validity of propositions 2 and 3 .

A separation is defined as an observation such that the worker in question did not work during the subsequent month. Thus, SEPAR is a dummy equal to 1 in the last month during which the worker was employed. Those workers who work through July, 1995 (the last month for which data are available) have SEPAR=0 for every month in which they worked. A worker who was employed say from January, 1994 through February, 1995 would have SEPAR=0 in every month of employment, except for February, 1995, when SEPAR would equal 1.

Table 4 reports the results of logits with SEPAR as the dependent variable. First note that the effect of PPPFLAG is positive. Converted to probabilities, it implies that the move to PPP increases turnover by about $7 / 10$ of a percentage point per month, or about $20 \%$ of the turnover rate. This is not surprising. A major change in the pay system may make some of the incumbents unhappy enough to leave. Given the guarantee, it is more likely that the change in the pay structure signaled tougher times ahead for low ability workers. Alternatively, the firm may have become less tolerant 
of workers at the bottom end who constantly were paid more than the PPP calculation would imply. Second, the coefficient on UAD is negative. More able workers are less likely to separate from the firm, probably reflecting the firm's happiness with more productive workers.

How does the PPP program sort workers? Does it induce the least able to stay and the most able to go? The answer is contained in logit 2 of table 4 . There, an interaction effect is included. If the PPP plan induces the least able to leave and the most able to stay, then the coefficient on (UAD)( PPPFLAG) should be negative. In all specifications tried, the coefficient on this interaction was negative.

This is precisely what theory predicts. The most able were the least happy with the hourly wage structure. A switch to piece rates keeps reduces the turnover rate of high productivity workers relative to that of low productivity workers. The effect of PPP on turnover varies substantially with the worker's productivity level. At $\mathrm{UAD}=4.4$, which is about the 90 th percentile of worker productivity, an additional unit of UAD is associated with an incremental decline in the turnover rate from switching to PPP of about 1.4 percentage points, which is over one third of the monthly turnover rate. 


\section{Table 4}

\section{Logits of SEPAR on Productivity Measures}

Number of observations: 38764

All Logits Include Month and Year Dummies

\begin{tabular}{|l|l|l|l|l|l|}
\hline Logit \# & PPPFLAG & UAD & UAD $^{2}$ & $\begin{array}{l}\text { UAD* } \\
\text { PPPFLAG }\end{array}$ & $\begin{array}{c}\text { Log } \\
\text { Like- } \\
\text { lihood }\end{array}$ \\
\hline 1 & $\begin{array}{l}.201 \\
.091)\end{array}$ & $\begin{array}{l}-.111 \\
(.022)\end{array}$ & & & -4568 \\
\hline 2 & $\begin{array}{l}.460 \\
(.147)\end{array}$ & $\begin{array}{l}-.129 \\
(.043)\end{array}$ & $\begin{array}{l}.009 \\
(.003)\end{array}$ & $\begin{array}{l}-.092 \\
(.043)\end{array}$ & -4566 \\
\hline
\end{tabular}

The effect of differential changes in turnover rates, hiring policy and incentives can be summarized in the following histograms. Figure 3 shows a histogram of productivity in January, 1994 when all workers were being paid hourly wages. Figure 4 shows the histogram in June, 1995 when all were on PPP. The mass in the later histogram lies to the right of the earlier one. In January, 1994, the modal worker produced between 2 and 3 units per day. In June, 1995, the modal worker produced between 3 and 4 units per day. 
Figure 3

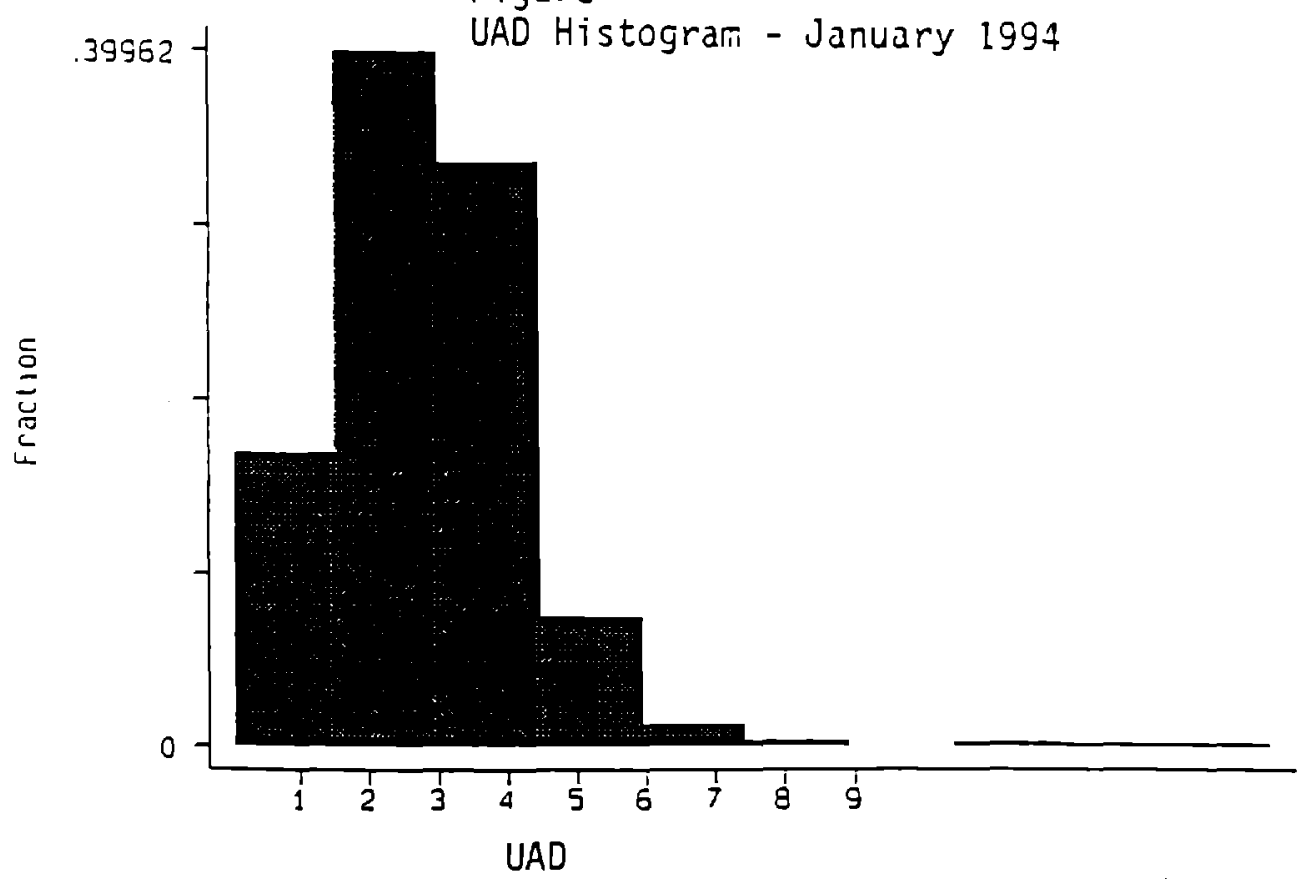

Figure 4

UAD Histogram - June 1995

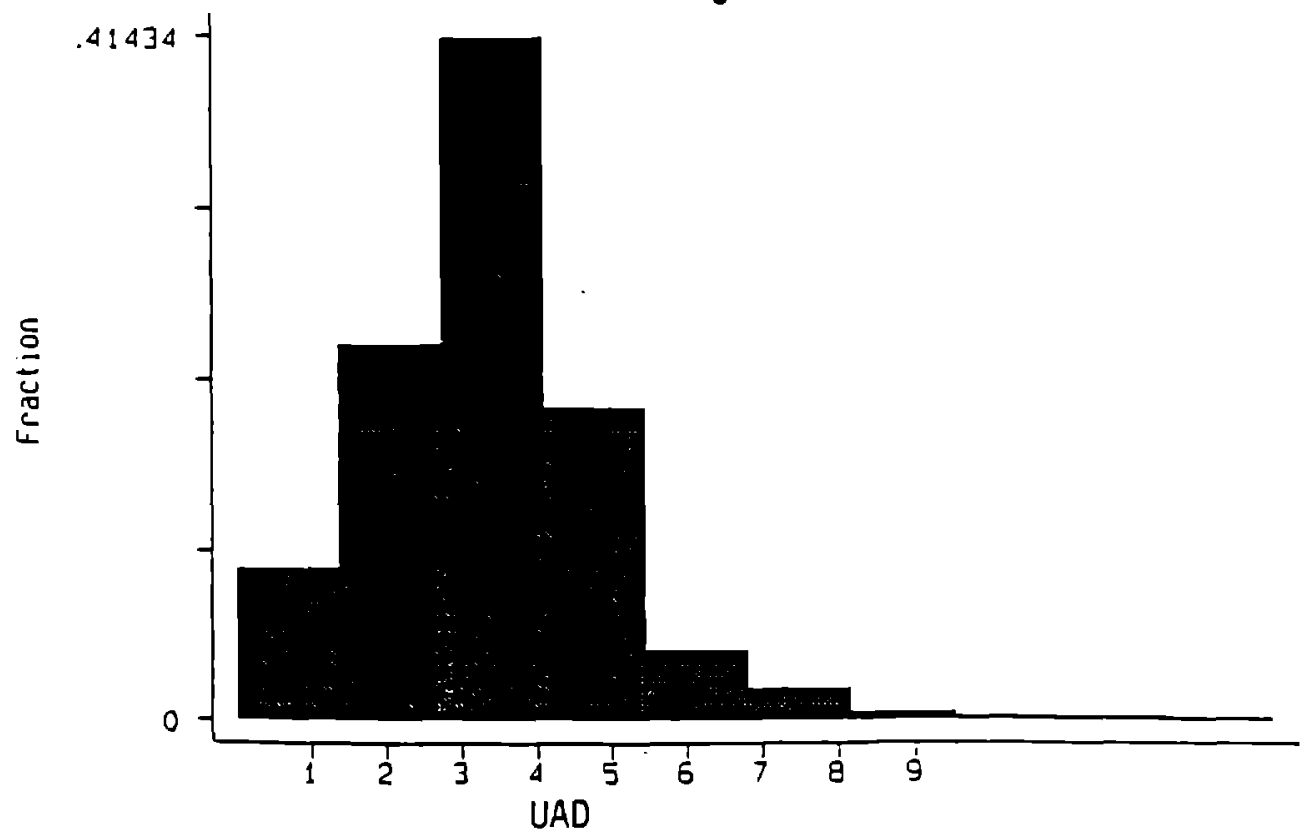




\section{New Hires:}

The theory taken literally implies that the average ability of workers hired after the switch to piece rates should be higher than the average ability of those hired before the switch. While ability

cannot be observed, output can. Average output is used as a proxy for ability. For each worker, $\overline{e_{p}}$, the worker specific average output under piece rates, is computed. The sample is split into those who were hired into the piece rate regime and those who were hired before piece rates took effect. The mean level of post-piece rate output among those hired when hourly wages were in effect was 3.17 . The mean among those hired after the piece rate came into effect was only 3.00 .

The fact that average output is higher among those hired under the hourly wage regime is not surprising. Earlier hires have higher levels of tenure. Given that the effect of tenure on productivity for piece rate workers is $36 \%$ per year (according to table 3), and given that the post-piece rate hires have only $5 \%$ lower productivity than pre-piece rate hires, the tenure effect is likely to account for more than the difference between groups, suggesting that the post-piece rate hires are more productive, tenure adjusted.

\section{Profitability:}

Table 2 reported that the cost per unit was lower under piece rates than under hourly wages. But it is possible to analyze the change in profits somewhat more systematically. After all, moving to piece rates would not be desirable from the firms point of view if more than the increase in productivity were eaten up by increased compensation costs.

In fact, the reverse was true by a significant margin. A regression of the log of pay per day on PPPFLAG was run, holding year and month constant. This regression is identical to regression 1 of table 3 , except that $\log$ of pay rather than $\log$ of output is the dependent variable. The coefficient 
on PPPFLAG is .066 with a standard error of .005 . Recall that the total effect on worker productivity was .36 (from table 3 ). Thus, there is a $36 \%$ increase in productivity per worker, but only a $6.5 \%$ increase in wage cost. This reflects two factors. First, not all of the gains were given to the existing work force. They were shared: As will be seen below, half went to the existing workers and half went to the firm. Second, the group of workers who are on board when piece rates are paid are more cost effective than the group of workers who were on board when hourly wages were paid. In large part, this reflects higher levels of productivity for the typical worker in the piece rate regime, which reduces costs per worker. Low productivity, high hourly wage workers have been replaced by higher productivity, primarily piece rate workers.

This can be seen in more detail by holding person effects constant. A regression was run, with the log of pay per day as dependent variable, on PPPFLAG including person, year and month dummies. The regression is identical to the previous one except that individual constant terms are included. It is also identical to regression 2 of table 3, except that log of pay rather than $\log$ of output is the dependent variable. The coefficient on PPPFLAG is .096 with a standard error of .004. Thus, pay went up for a given employee by $9.6 \%$ on average after PPP was instituted. But table 3 shows that productivity for a given worker increased by $20 \%$, which means that incumbents captured about half of the return to the increase in their own productivity.

Did profits rise? This depends on the increase in productivity relative to the increase in labor and other costs. Given the numbers (36\% increase in productivity, $6.6 \%$ increase in wages), it is unlikely that other variable costs of production (most importantly the glass and transportation costs) ate up the margin still given to the firm. The piece rate plan seems to have been implemented in a 
way that likely made both capital and labor better off. ${ }^{15}$

There is one cost that has been ignored throughout. Piecework requires measurement of output. In Safelite's case, the measurement comes about through a very sophisticated computerized system. But the system involves people and machines that are costly. Indeed, in equilibrium, firms that pay hourly wages or monthly salaries are probably those for whom measurement costs exceed the benefits from switching to output based pay.

In this case, the gains in productivity were very large. Further, the information systems were initially put in place for reasons other than monitoring worker productivity, having to do with inventory control and reduced installation lags. The economies of scope in information technology, coupled with the labor productivity gains, are probably large enough to cover whatever additional cost of monitoring was involved. This is not always so. Whenever a firm switches from one pay system to another, it is almost certain that one system does not maximize profit. But Safelite has no apparent desire to return to the previous pay system.

\section{Sick Leave:}

Units-per-associate-per-day are only one measure of productivity. Other measures are available. One that is of interest is paid sick time. To the extent that workers can earn more by coming ${ }^{12}$ to work than by taking the default sick day compensation, PPP created incentives for workers to spend more time on the job and less time taking paid sick leave. Indeed, the mean level of paid sick hours fell by almost $60 \%$ after PPP was instituted. Most of this effect took the form of

\footnotetext{
${ }^{15}$ The firm's earnings are up substantially since the switch to piece rates, but this could reflect other factors as well.
} 
sorting. There was virtually no effect of PPP on sick hours, once person dummies were included. Virtually all of the effect resulted from turnover. Workers who were most likely to take sick leave left and those who were least likely to take sick leave were hired. These effects, while significant, are not particularly important to the company because a small fraction of the workforce is eligible for sick pay.

\section{Quality:}

One defect of paying piece rates is that quality may suffer. ${ }^{16}$ In the Safelite case, most quality problems show up rather quickly in the form of broken windshields. Since the guilty installer can be easily identified, there is an efficient solution to the quality problem: The installer must reinstall the windshield on his own time and must pay the company for the replacement glass before any paying jobs are assigned to him. This induces the installer to take the appropriate amount of care when installing the glass in the first place.

Safelite uses another system that relies on peer pressure. ${ }^{17}$ When a customer reports a defect, the job is randomly assigned to a worker in the shop that was responsible for the problem. The worker is not paid for doing the repair work. But workers know the identity of the initial installer. If one installer causes his peers to engage in too many re-dos, his co-workers pressure him to improve or resign.

\section{Implications:}

The results imply that productivity effects associated with the switch from hourly wages to piece rates are quite large. The theory implies that a switch should bring about an increase in average

\footnotetext{
${ }^{16}$ See Lazear (1986) and Baker (1992).

${ }^{17}$ See Kandel and Lazear (1992) for a discussion of the effects of peer pressure and norms in an organization.
} 
levels of output and in its variance. These predictions are borne out. The theory does not imply that profits must rise. Market equilibrium is characterized by firms that choose a variety of compensation methods. Firms choose the compensation scheme by comparing the costs and benefits of each scheme. The benefit is a productivity gain. Costs may be associated with measurement difficulties, undesirable risk transfers, and quality declines.

It is interesting that the productivity gains are so large for this particular firm. Of course, this is only one data point and it is one where the case for piece rates seems especially strong. Output is easily measured and quality problems are detected and blame is assignable. Managerial and professional jobs may not be as well suited to piecework. The fact that the productivity gains are so large in this case is worthy of attention. The results do not imply that all firms should switch to piece rate pay.

\section{Summary and Conclusion:}

The theory above reveals average output per worker and average worker ability should rise when a firm switches from hourly wages to piece rates. The minimum level of ability does not change, but more able workers, who shunned the hourly wage, are attracted by piece rates. As a result of incentive effects, average output per worker rises. Thus, average ability and output, as well as variance in ability and output, should rise when a firm switches from hourly wages to piece rates.

The effects of changing compensation method were estimated using worker level monthly output data from Safelite Autoglass Company. The theory is borne out almost to the letter. Moving to a piece rate regime is associated with a $36 \%$ increase in productivity for the company as a whole. Part of the gain reflects sorting, part reflects incentives, and some reflects the pattern in which the scheme was implemented. For a given individual, switching to piece rates increased productivity by 
about $20 \%$.

Tenure effects associated with productivity are large. The average worker's productivity increased by $36 \%$ in one year after piece rate pay was adopted.

Turnover rates rise after the change in compensation method, but the pattern of turnover is in direct support of the theory. There is a general increase in turnover of all groups, except for the most able. Piece rates appeal to the most able, but are less attractive to other groups of workers. As a result, coupled with a wage guarantee, the result of the switch to piece rate pay is increased heterogeneity, both in output and ability.

An analysis of paid sick leave reveals that piece rate pay reduced the amount of paid sick leave, probably because piece rates increase the relative cost of taking sick leave.

Workers captured some of the return from moving to piece rates. The average incumbent worker's wages rose by $9.6 \%$ as a result of the switch. This accounts for about half of the gain in productivity for the given worker. No data on the costs of implementing the program are available, but is unlikely that in this instance the costs swamp the huge productivity gains associated with moving to piece rates. 


\section{References}

Baker, George. "Incentive Contracts and Performance Measurement," Journal of Political Economy 100 (June 1992): 598-614.

Brown, Charles. "Wage Levels and Methods of Pay," Rand Journal 23 (Autumn 1992): 366-75.

Fama, Eugene F. "Time, Salary, and Incentive Payoffs in Labor Contracts," Journal of Labor Economics 9 (January 1991): 25-44.

Fernie, Sue and David Metcalf "It's Not What You Pay It's the Way That You Pay It and That's What Gets Results" Jockeys' Pay and Performance, Centre for Econ. Performance Disc. Paper \#295, LSE, 1996.

Kandel, Eugene, and Lazear, Edward P. "Peer Pressure and Partnerships," Journal of Political Economy 100(4) (August 1992): 801-17.

Lazear, Edward P. 'Salaries and Piece rates," Journal of Business 59 (July 1986): 405-31.

Lazear, Edward P., and Rosen, Sherwin. "Rank-Order Tournaments as Optimum Labor Contracts," Journal of Political Economy 89 (October 1981): 841-64.

Paarsch, Harry J.and Bruce S. Shearer."Fixed Wages, Piece Rates, and Intertemporal Productivity: A Study of Tree Planters in British Columbia," unpub. manuscript, 1996.

Slichter, Sumner. Modern Economic Society New York: Henry Holt and Company, 1928. 